\title{
Isolation and Identification of Secondary Metabolite from Marine Sponge Callyspongia sp. and its Antibacterial Potency
}

\author{
Adryan Fristiohady 1*D, Agung W Mahatva Yodha 1, Baru Sadarun ${ }^{2}$, La Ode Muhammad Julian

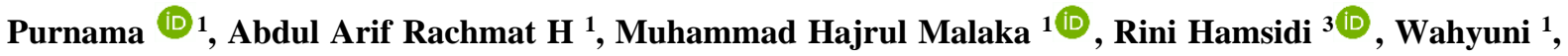 \\ Wa Ode Salma ${ }^{4}$, Wa Ode Sitti Musnina ${ }^{5}$, Idin Sahidin ${ }^{1}$ (D)
}

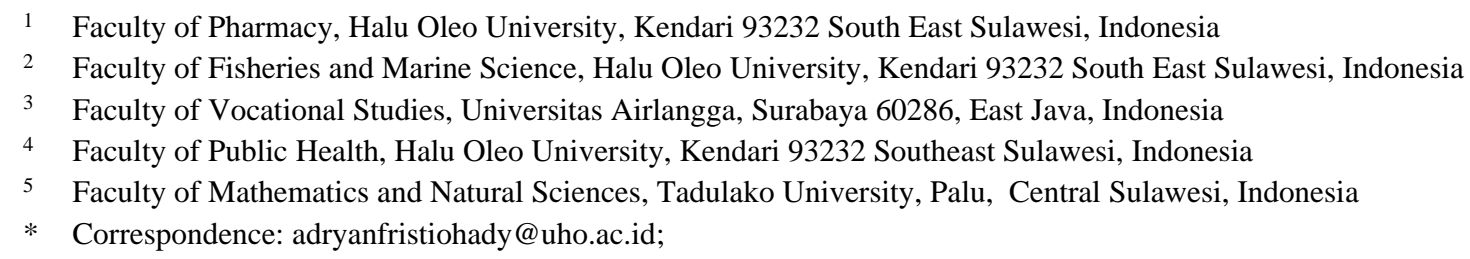

Received: 19.09.2020; Revised: 9.10.2020; Accepted: 9.10.2020; Published: 12.10.2020

\begin{abstract}
Marine sponge Callyspongia sp. is one full of potency as a source for discovering and developing novel antibacterial. This study aims to isolate the Callypsongia sp. and assay their antibacterial activity. Callyspongia sp. were macerated with ethyl acetate ( $3 \times 24 \mathrm{hrs})$, isolated with vacuum liquid chromatography (VLC) and RC (radial chromatography), and determined their structure with ${ }^{1} \mathrm{H}$ and ${ }^{13} \mathrm{C}$-NMR. The antibacterial activity was assayed with the microdilution method. From ethyl acetate extract of Callyspongia sp. was successfully 2 isolated compounds, namely, isolate $\mathrm{C} 1$ (cholesterol) and isolate C2 (Unknown alkaloid with carbonyl from aldehyde group). The extract has MIC $>512 \mu \mathrm{g} / \mathrm{mL}$ against Bacillus subtilis, Escherichia coli, Streptococcus mutans, and Salmonella enterica. While in both isolates provided MIC value $>256 \mu \mathrm{g} / \mathrm{mL}$ against B. subtilis, E. coli, and $S$. mutans, yet in $S$. enterica provided $128 \mu \mathrm{g} / \mathrm{mL}$ for isolate $\mathrm{C} 1$ and $256 \mu \mathrm{g} / \mathrm{mL}$ for isolate $\mathrm{C} 2$. In conclusion, ethyl acetate extract of Callyspongia sp. contains cholesterol and Unknown alkaloid with carbonyl from the aldehyde group, and they both exhibited low antibacterial susceptibility.
\end{abstract}

Keywords: Callyspongia sp.; isolation; VLC; RC; antibacterial; microdilution.

(C) 2020 by the authors. This article is an open-access article distributed under the terms and conditions of the Creative Commons Attribution (CC BY) license (https://creativecommons.org/licenses/by/4.0/).

\section{Introduction}

Sponges are one of the biota components that make up coral reefs that are quite widely distributed. There are 15,000 species of sponges worldwide, and about $45 \%$ of bioactive compounds are found in sponges [1]. Sponges are marine natural products that potential as a source for novel drug discoveries. Many pharmacological activities are reported in sponges, including cytotoxic, kinase inhibitor, antibacterial, antiviral, antihyperlipidemic, antiproliferative, immunomodulatory, and anti-inflammatory [2-4]. The discovery of novel drugs from marine sources began in the mid-1970 and reported about 2500 new metabolites are found [5].

Callyspongia sp. is a sponge found in almost all Indonesian sea so that it is easily obtained [6]. It contains various secondary metabolites that can be used as a source of drugs 
[7]. It reported having anticancer, antioxidant, immunomodulator, anti-inflammatory, antimicrobial and antiparasitic activity [8-10].

Infectious disease is a significant problem globally; one of them is a bacterial infection. To treat a bacterial infection, it requires antibiotics. However, the resistance of antibiotics is another major problem that occurs. Thus, it urgent to discover and develop novel antibiotics or antibacterial agents from natural products. Marine sponges provide many biological compounds that act as antibacterial $[11,12]$.

One of the steps in discovering the novel drug is by isolating secondary metabolites in marine natural products. The isolation method is a technique of separating a component from a more complex mixture. The basis of this separation technique is the comparison of the properties of the component partition against the adsorbent [13]. The isolation process that must be carried out to obtain pure compounds includes extraction, fractionation, and purification [14]. According to the explanation above, we aim to isolate the secondary metabolite from marine sponge Callyspongia sp. and assay the extract and isolates' antibacterial activity.

\section{Materials and Methods}

\subsection{Materials.}

The material used was marine sponge Callyspongia sp., Bacillus subtilis, Escherichia coli, Streptococcus mutans, Salmonella enterica. The chemical was methanol (Merck ${ }^{\circledR}$ ), ethyl acetate $\left(\operatorname{Merck}^{\circledR}\right)$, n-hexane $\left(\operatorname{Merck}^{\circledR}\right)$, chloroform $\left(\operatorname{Merck}^{\circledR}\right)$, distilled water, silica gel $60 \mathrm{GF}_{254}$ $\left(\operatorname{Merck}^{\circledR}\right)$, silica $60 \mathrm{G}\left(\operatorname{Merck}^{\circledR}\right)$, cerium sulfate/ CuSO $4\left(\right.$ Merck $\left.^{\circledR}\right)$, Nutrient Agar/NA $\left(\right.$ Merck $\left.^{\circledR}\right)$, and Nutrient Broth/NB $\left(\right.$ Merck $\left.^{\circledR}\right)$. The apparatus used were a set of vacuum liquid chromatography (VLC), a set of radial chromatography (RC), a vacuum rotary evaporator $\left(\right.$ Buchi $\left.^{\circledR}\right)$, micropipette (Eppendorf $\left.{ }^{\circledR}\right), \quad$ Microwell plate (Greiner Bio-One () , spectrophotometer (Jenway), and NMR ${ }^{1} \mathrm{H}$ and ${ }^{13} \mathrm{C}$ spectra (JEOL).

\subsection{Extraction and isolation.}

A total of $259.7 \mathrm{~g}$ of dried extract of Callyspongia sp. was macerated with ethyl acetate (EtOAC) $(1: 10 \mathrm{w} / \mathrm{v})$ for $3 \times 24 \mathrm{hrs}$. The extract was concentrated under vacuum condition with a rotary evaporator $\left(55^{\circ} \mathrm{C}\right)$ and yielded a total of $37.17 \mathrm{~g}$ concentrated extract $(14.31 \%)$.

The extract was fractioned by vacuum liquid chromatography (VLC) and a mixture of n-hexane: ethyl acetate $(7: 3 \mathrm{v} / \mathrm{v})$. The fraction was performed till obtained 7 fractions, which were Fraction A (1.371 g); fraction B (4.9 g); fraction C (4.7 g); fraction D (94 mg); fraction E (94 mg); fraction F (77 mg); and fraction G (5.8 g). Fraction A was continued fractioned using VLC with eluent n-hexane: ethyl acetate $(7: 3 \mathrm{v} / \mathrm{v})$ and obtained 20 fractions. The fraction 11 was a pure compound, coded as isolate $\mathrm{C} 1$. Other fractions were combined and obtained 8 main fractions, namely fractions 1-8. Fraction $6(1.4 \mathrm{mg})$ was separated with radial chromatography $(\mathrm{RC})$ with eluent dichloromethane: methanol $(9: 1 \mathrm{v} / \mathrm{v})$ and obtained 14 fractions. Fraction 11 (10.2 mg) was a pure compound, coded as isolate C2.

\subsection{Structure determination.}

The structure of isolates was determined with ${ }^{1} \mathrm{H}$ NMR and ${ }^{13} \mathrm{C}$ NMR. The data obtained were compared to existed references. 


\subsection{Antibacterial activity.}

Antibacterial activity was conducted according to the microdilution method. The bacteria used were Bacillus subtilis, Escherichia coli, Streptococcus mutans, and Salmonella enterica and incubated in nutrient agar (NA) at $37^{\circ} \mathrm{C}$ for $24 \mathrm{hrs}$. After that, the inocula were suspended in $0.9 \% \mathrm{NaCl}$ to obtain the turbidity equivalent to $0.5 \mathrm{McFarland}$. A total of $100 \mu \mathrm{l}$ media was put in each well of a microplate, continued by pipetting $100 \mu \mathrm{l}$ of the sample into first wells and pipetting $100 \mu \mathrm{l}$ the mixture to second wells, and so on up to the eighth wells to obtain concentrations $512-0.5 \mu \mathrm{g} / \mathrm{mL}$. It was also conducted to chloramphenicol and DMSO for control. Following that, $100 \mu \mathrm{l}$ of bacterias were added to wells. They were incubated for $16-20 \mathrm{hrs}$ at $37^{\circ} \mathrm{C}$ and measured under spectrophotometer.

\section{Results and Discussion}

The spectra ${ }^{13} \mathrm{C}-\mathrm{NMR}$ of isolate $\mathrm{C} 1$ exhibited 27 of carbons with 2 signals. The carbon is a typical methine carbon group of olefins that appeared at $\delta \mathrm{C} 121.8 \mathrm{ppm}$ and $\delta \mathrm{C} 140.8 \mathrm{ppm}$. Other methine carbon derived from alkane chains at $\delta \mathrm{C} 56.8 \mathrm{ppm}$ and $50.2 \mathrm{ppm}$, methylene carbon at $\delta \mathrm{C} 21.1-42.3 \mathrm{ppm}$, and methyl carbon at $\delta \mathrm{C} 11.94$ - $19.4 \mathrm{ppm}$ (Figure 1).

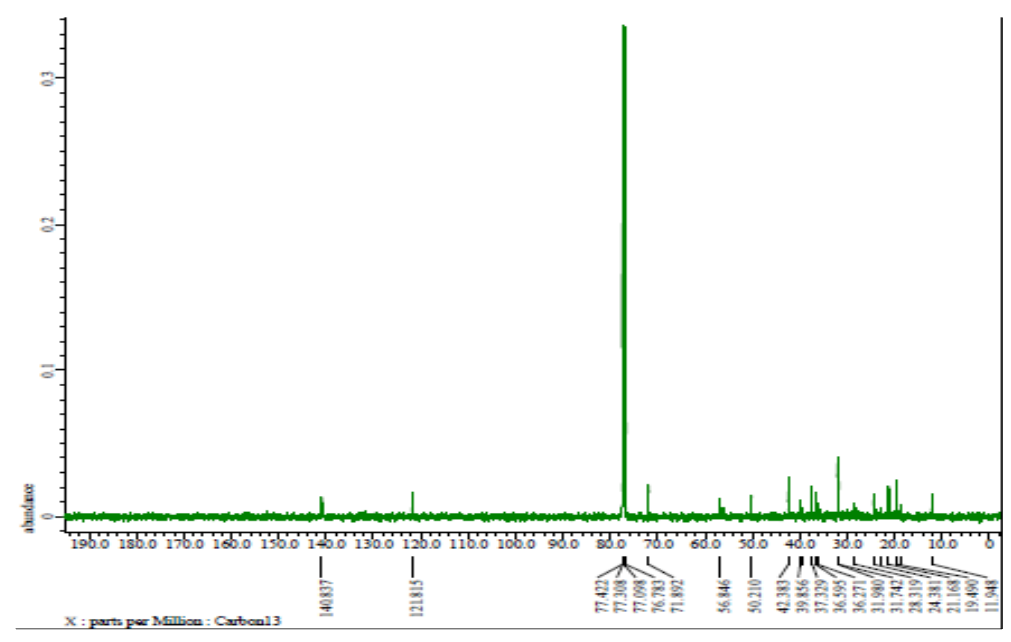

Figure 1. The Spectra ${ }^{13} \mathrm{C}-\mathrm{NMR}$ of Isolate $\mathrm{C} 1$.

The ${ }^{13} \mathrm{C}-\mathrm{NMR}$ analysis was also supported by the presence of a ${ }^{1} \mathrm{H}-\mathrm{NMR}$ signal for the isolate $\mathrm{C} 1$ (Figure 2). ${ }^{1} \mathrm{H}-\mathrm{NMR}$ analysis on $\mathrm{C} 1$ isolates exhibited 46 protons, 4 of which had a fairly large chemical shifting at $5.3 ; 5.1 ; 4.7$; and $3.5 \mathrm{ppm}$. This magnitude indicates that the proton has a minimal electron density. Besides, the ${ }^{1} \mathrm{H}-\mathrm{NMR}$ spectrum exhibited the buildup of protons with extensive integration. From the ${ }^{1} \mathrm{H}$ and ${ }^{13} \mathrm{C}-\mathrm{NMR}$ data, it can be estimated that the molecular formula for isolate $\mathrm{C} 1$ is $^{\mathrm{C}_{27}} \mathrm{H}_{46} \mathrm{O}$. It is similar to cholesterol (Kalinowski et al., 1984). The data was: Cholesterol (1), ${ }^{1} \mathrm{H}$ NMR (500 MHz, $\left.\mathrm{CDCl}_{3}\right) \delta \mathrm{H}(\mathrm{ppm}): 1.82$ (m, H-4); 1.49 ( $m, \mathrm{H}-12) ; 1.33$ (1H, $m, \mathrm{H}-16) ; 1.26$ ( $m, \mathrm{H}-23) ; 1.12$ ( $m, \mathrm{H}-1) ; 0.82$ ( $m, \mathrm{H}-11)$; and 0.67 (m, H-24). ${ }^{13} \mathrm{C} \mathrm{NMR}\left(125 \mathrm{MHz}, \mathrm{CDCl}_{3}\right) \delta \mathrm{C}(\mathrm{ppm}): 77.0$ (C-25); 76.8 (C-17); $76.6(\mathrm{C}-14) ; 71.8$ (C-3); 56.8 (C-13); 50.2 (C-9); 42.3 (C-4); 39.8 (C-12); 39.7 (C-22); 39.5 (C-20); 37.3 (C-10); 36.2 (C-16); 31.9 (C-8); 31.7 (C-25); 31.7 (C-2); 3.65 (C-1); 28.3 (C-7); 28.3 (C-23); 24.3 (C15); 22.9 (C-26); 21.1 (C-11); 19.4 (C-19); 18.8 (C-21); 140.8 (C-5); 121.8 (C-6); 12.2 (C-27); and $11.9(\mathrm{C}-18)$. 


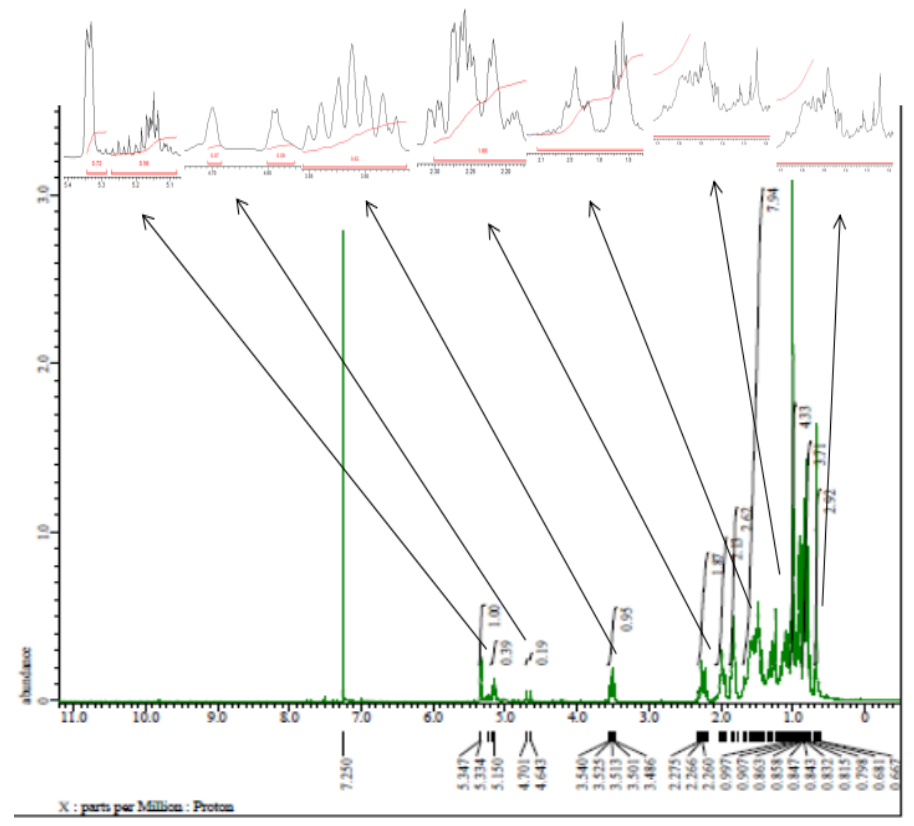

Figure 2. The Spectra ${ }^{1} \mathrm{H}-\mathrm{NMR}$ of Isolate $\mathrm{C} 1$.

The C2 compound is obtained as a yellow solid. This compound exhibited dark spots on UV rays 254, spots are not visible at $366 \mathrm{~nm}$ light and after derivatization using, cerium sulfate followed by heating. According to the ${ }^{13} \mathrm{C}-\mathrm{NMR}$ analysis of isolate $\mathrm{C} 2$ there was 10 carbon on its structure. Carbon at chemical shifting above 90 ppm, which were 125.8; 132.3; 176.6, and $178.0 \mathrm{ppm}$ were olefin or Csp2 carbon. These four olefinic carbons allow the formation of two double bonds. The ${ }^{13} \mathrm{C}-\mathrm{NMR}$ spectrum exhibited 12 types of carbon with 4 carbon peaks in this compound: a specific group, namely the quaternary carbon of the alkene group, which appeared at 178.06 and $176.63 \mathrm{ppm}$, and the methine carbon of the alkene group appeared at 132.37 and $125.85 \mathrm{ppm}$. Another methylene carbon derived from the alkane chain also appeared at 47.07-49.33 ppm (Figure 3).

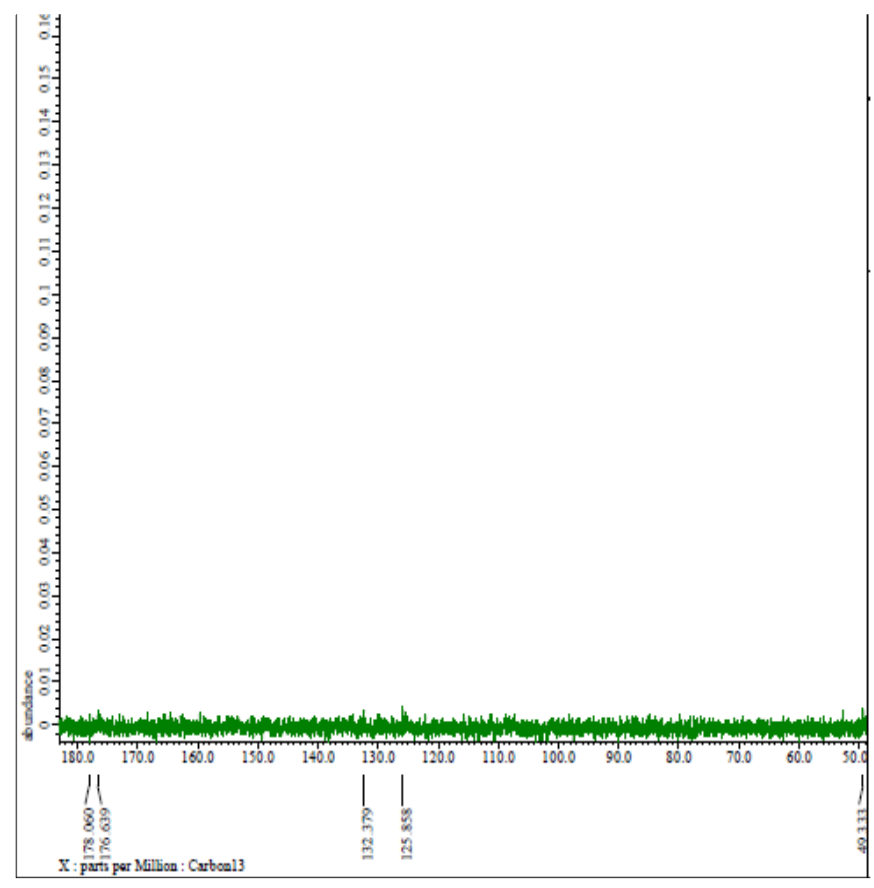

Figure 3. The Spectra ${ }^{13} \mathrm{C}-\mathrm{NMR}$ of Isolate $\mathrm{C} 2$. 


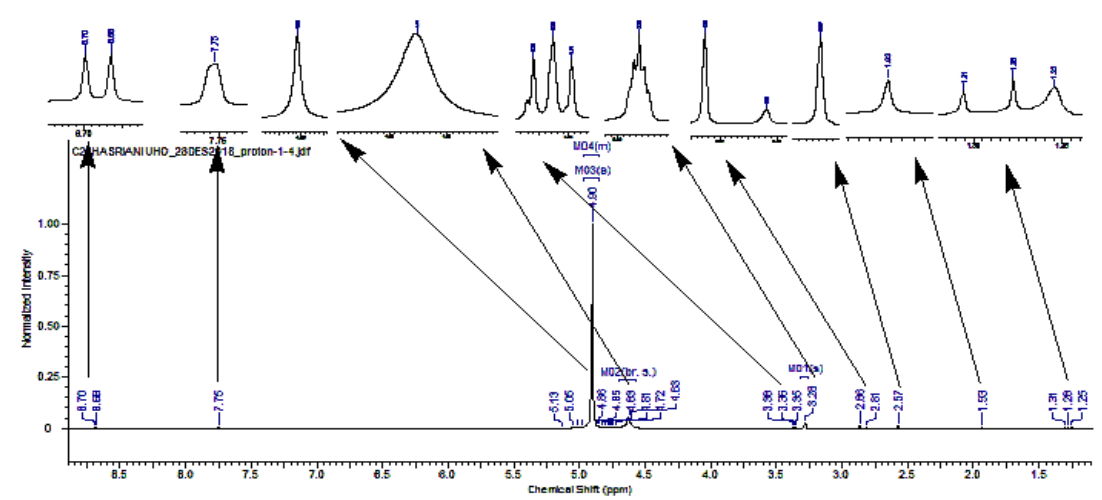

Figure 4. The Spectra ${ }^{1} \mathrm{H}-\mathrm{NMR}$ of Isolate $\mathrm{C} 2$.

The 1H-NMR data exhibited 10 protons, 4 of which have a fairly large chemical shear, namely, $8.70 ; 7,75 ; 4.90$, and $4.63 \mathrm{ppm}$. This magnitude indicates that the proton has a minimal electron density. The $1 \mathrm{H}-\mathrm{NMR}$ spectrum of compound $\mathrm{C} 2$ shows 10 protons consisting of methylene protons $(1.28 ; 1.93 ; 2.58$, and $2.86 \mathrm{ppm})$ and methyne protons $(7.75 \mathrm{ppm})$. From the ${ }^{1} \mathrm{H}$ and ${ }^{13} \mathrm{C}-\mathrm{NMR}$ data, it can be estimated that the molecular formula for the isolate $\mathrm{C} 2$ is $\mathrm{C}_{12} \mathrm{H}_{10}$ (Figure 4). The data was: Unknown alkaloid with carbonyl from aldehyde group (2); yellow solid. Spectra of ${ }^{1} \mathrm{H}$ NMR $\left(500 \mathrm{MHz}, \mathrm{CDCl}_{3}\right) \delta \mathrm{H}(\mathrm{ppm}): 8.7$ (d, H-1); 7.75 (s, H-2); 4.9 $(s, \mathrm{H}-3)$; 4.63 ( $s, \mathrm{H}-4) ; 3.38$ ( $t$, H-5); 3.28 ( $m, \mathrm{H}-6) ; 2.86$ (d, H-7); 2.58 ( $s, \mathrm{H}-8)$; 1.93 (s, H-9); 1.28 ( $m, \mathrm{H}-10)$. Spectra of ${ }^{13} \mathrm{C}$ NMR $\left(125 \mathrm{MHz}, \mathrm{CDCl}_{3}\right) \delta \mathrm{C}(\mathrm{ppm}): 178.06(\mathrm{C}-1) ; 176.63(\mathrm{C}-$ 2); 132.37 (C-3); 125.85 (C-4); 49.33 (C-5); 48.33 (C-6); 48.12 (C-7); 47.9 (C-8); 47.69 (C-9); 47.47 (C-10); 47.2 (C-11); and 47.05 (C-12).

According to the isolation and purification process, followed by structure determination, it was obtained 2 isolates, which were cholesterol (1) and unknown alkaloid with carbonyl from the aldehyde group (2). The structure of cholesterol is presented in Figure 5. The isolate 2 structure is undetermined with ${ }^{1} \mathrm{H}-\mathrm{NMR}$ and ${ }^{13} \mathrm{C}-\mathrm{NMR}$.

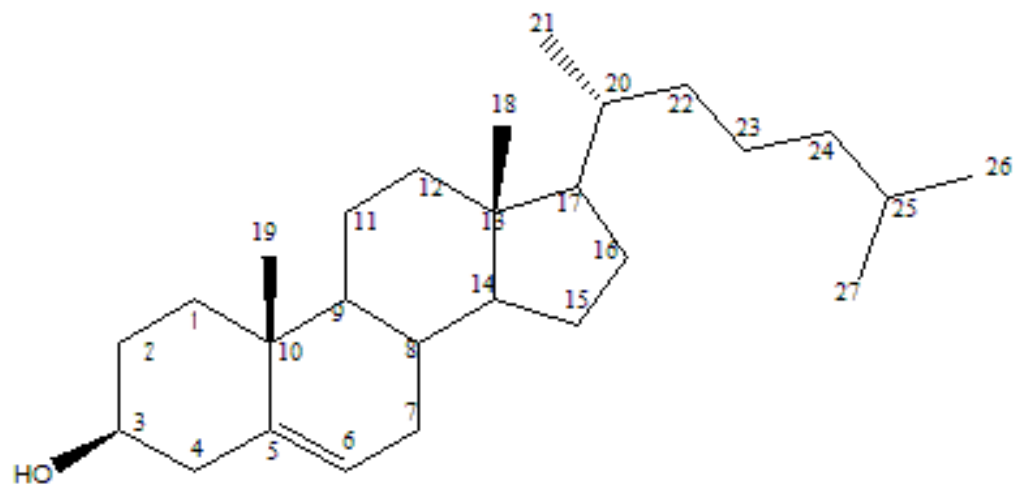

Figure 5. Cholesterol.

According to the antibacterial activity assay, the ethyl acetate extract of Callyspongia sp. was not demonstrating antibacterial activity with MIC value more than $512 \mu \mathrm{g} / \mathrm{mL}$ against all bacteria used. Simultaneously, the isolate $\mathrm{C} 1$ and isolate $\mathrm{C} 2$ provided MIC value more than $256 \mu \mathrm{g} / \mathrm{mL}$, except for S. enterica with 128 dan $256 \mu \mathrm{g} / \mathrm{mL}$, respectively (Table 1). Based on other studies showed that ethyl acetate extract was providing the lowest antibacterial activity against bacteria, it could be the reason the ethyl acetate extract of Callyspongia sp. was not providing antibacterial potency. The flavonoid, tannin, and phenolics contain in ethyl acetate extract was the lowest compared to methanolic or ethanolic extract [15]. Flavonoids, tannins, 
and phenolic compounds are bioactive agents with many potencies, one of them as antibacterial by various mechanisms [16-18].

Table 1. MIC of Extract and Isolates from Callyspongia sp.

\begin{tabular}{l|l|l|l|l}
\multirow{2}{*}{ Sample } & \multicolumn{4}{l}{ MIC Value $(\boldsymbol{\mu g} / \mathbf{m L})$} \\
\cline { 2 - 5 } & B. subtilis & S. mutans & E. coli & S. enterica \\
\hline EtoAC of Callyspongia sp. & $>512$ & $>512$ & $>512$ & $>512$ \\
\hline Isolate C1 & $>256$ & $>256$ & $>256$ & 128 \\
\hline Isolate C2 & $>256$ & $>256$ & $>256$ & 256 \\
\hline Chloramphenicol & 8 & 8 & 8 & 8
\end{tabular}

The control used was chloramphenicol. Chloramphenicol is an antibiotic that is used to treated infectious diseases. The chloramphenicol acts by binding to ribosome $50 \mathrm{~S}$ of bacteria, thereby inhibiting bacteria's protein synthesis $[19,20]$. The MIC of chloramphenicol were 8 $\mu \mathrm{g} / \mathrm{mL}$ (Table 1).

\section{Conclusions}

2 isolates were successfully isolated from Callyspongia sp., which were cholesterol and un-identified alkaloid, coded as C1 and C2. The extract of Callyspongia sp. was not exhibiting antibacterial properties against B. subtilis, S. mutans, E. coli, and S. enterica. On the other hand, isolate $\mathrm{C} 1$ and $\mathrm{C} 2$ were only exhibiting antibacterial properties against $S$. enterica according to MIC test.

\section{Funding}

This research was funded by the Ministry of Research, Technology, and Higher Education of the Republic of Indonesia for with Hibah Penelitian Dasar Scheme 2019 with Contract no: 519a/UN29.20/PPM/2019.

\section{Acknowledgments}

We would like to thanks the Ministry of Research, Technology, and Higher Education of the Republic of Indonesia.

\section{Conflicts of Interest}

The authors declare no conflict of interest.

\section{References}

1. Youssef, D.T.A.; Shaala, L.A.; Asfour, H.Z. Bioactive Compounds from the Red Sea Marine Sponge Hyrtios Species. Marine Drugs 2013, 11, 1061-107, https://doi.org/10.3390/md11041061.

2. El-Demerdash, A.; Atanasov, A.G.; Horbanczuk, O.K.; Tammam, M.A.; Abdel-Mogib, M.; Hooper, J.N.A.; Sekeroglu, N.; Al-Mourabit, A.; Kijjoa, A. Chemical Diversity and Biological Activities of Marine Sponges of the Genus Suberea: A Systematic Review. Marine Drugs 2019, 17, 1-14, https://doi.org/10.3390/md17020115.

3. Wahyuni, W.; Fristiohady, A.; Malaka, MH; Malik, F.; Yusuf, M.I.; Leorita, M.; Sadarun, B.; Saleh, A.; Musnina, W.O.S.; Sabandar, C.W.; Sahidin, I. Effects of Indonesian marine sponges ethanol extracts on the lipid profile of hyperlipidemic rats. Journal of Applied Pharmaceutical Science 2019, 9, 001-008, http://dx.doi.org/10.7324/JAPS.2019.91001.

4. Fristiohady, A.; Wahyuni, W.; Malaka, M.; Madu, D.; Muthalib, D.; Munasari, D.; Purnama, L.; Sadarun, B.; Ilyas, M.; Sahidin, S. Ethanolic Extract of Xestospongia Sp. Induces CD4+ and CD14 Cells Levels on Wistar Male Rat Infected with Staphylococcus aureus. Pharmacology and Clinical Pharmacy Research 2020, 5, 56-61, https://doi.org/10.15416/pcpr.v5i2.26986. 
5. Cragg, G.M.; Newman, D.J. Natural products: A continuing source of novel drug leads. Biochimica et Biophysica Acta (BBA) - General Subjects 2013, 1830, 3670-3695, https://doi.org/10.1016/j.bbagen.2013.02.008.

6. Warbung, Y.Y.; Wowor, V.N.S.; Posangi, J. Daya Hambat Ekstrak Spons Laut Callyspongia sp terhadap Pertubuhan Bakteri Staphylococcus aureus. Jurnal e-GIGI 2013, 1, 1-12, https://doi.org/10.35790/eg.1.2.2013.3151.

7. Satari, R.R. 1999. Penelitian Produk alam laut di Indonesia, arah dan prospek. Seminar Nasional Kimia Bahan Alam, Jakarta 1999, 29-37.

8. Ibrahim, H.A.H.; El-Naggar, H.A.; El-Damhougy, K.A.; Bashar, M.A.E.; Abou Senna, F.M. Callyspongia crassa and C. siphonella (Porifera, Callyspongiidae) as a potential source for medical bioactive substances, Aqaba Gulf, Red Sea, Egypt. The Journal of Basic and Applied Zoology 2017, 78, 1-10, https://doi.org/10.1186/s41936-017-0011-5.

9. Fristiohady, A.; Wahyuni, W.; Malik, F.; Purnama, LOMJ; Sadarun, B.; Sahidin, I. Anti-Inflammatory Activity Of Marine Sponge Callyspongia Sp. And Its Acute Toxicity. Asian Journal of Pharmaceutical and Clinical Research 2019, 12, 97-100, https://doi.org/10.22159/ajpcr.2019.v12i12.34737.

10. Fristiohady, A.; Leorita, M.; Malaka, MH; Hamsidi, R.; Azizah, N.; Fransiskus, R.; Purnama, LOMJ; Sadarun, B.; Sahidin, I. Immunomodulatory Activity of Callyspongia sp. Extract Towards Interferon-gamma (IFN- $\gamma$ ) and Tumor Necrosis Factor-Alpha (TNF- $\alpha$ ) Levels in Staphylococcus aureus - Induced Wistar Male Rats. Biointerface Research in Applied Chemistry 2021, 11, 9311-9317.

11. van der Meer, J.W.M. The infectious disease challenges of our time. Front Public Health 2013, 1, 1-2, https://doi.org/10.3389/fpubh.2013.00007.

12. Belete, T.M. Novel targets to develop new antibacterial agents and novel alternatives to antibacterial agents. Human Microbiome Journal 2019, 11, 1-8, https://doi.org/10.1016/j.humic.2019.01.001

13. Harborne, J.B. Metode Fitokimia: Penuntun Cara Modern MenganalisaTumbuhan. Edisi II, ITB Press, Bandung. 1996.

14. Sahidin, I. Mengenal Senyawa Alami, Unhalu Press, Kendari. 2012.

15. Trabelsi, A.; El Kaibi, MA; Abbasi, A.; Horchani, A.; Chekir-Ghedira, L.; Ghedira, K. Phytochemical Study and Antibacterial and Antibiotic Modulation Activity of Punica granatum (Pomegranate) Leaves. Scientifica (Cairo) 2020, 2020, 1-7, https://doi.org/10.1155/2020/8271203

16. Adamczak, A.; Ożarowski, M.; Karpiński, T.M. Antibacterial Activity of Some Flavonoids and Organic Acids Widely Distributed in Plants. J Clin Med 2020, 9, 1-17, https://doi.org/10.3390/jcm9010109.

17. Kaczmarek, B. Tannic Acid with Antiviral and Antibacterial Activity as A Promising Component of Biomaterials-A Minireview. Materials 2020, 13, 1-13, https://doi.org/10.3390/ma13143224.

18. Bouarab-Chibane, L.; Forquet, V.; Lantéri, P.; Clément, Y.; Léonard-Akkari, L.; Oulahal, N.; Degraeve, P.; Bordes, C. Antibacterial Properties of Polyphenols: Characterization and QSAR (Quantitative StructureActivity Relationship) Models. Microbiol 2019, 10, 1-23, https://doi.org/10.3389/fmicb.2019.00829.

19. Dinos, G.P; Athanassopoulos, C.M.; Missiri, D.A.; Giannopoulou, P.C.; Vlachogiannis, I.A., Papadopoulos, G.E.; Papaioannou, D.; Kalpaxis, D.L. Chloramphenicol Derivatives as Antibacterial and Anticancer Agents: Historic Problems and Current Solutions. Antibiotics (Basel) 2016, 5, 1-21, https://doi.org/10.3390/antibiotics5020020.

20. Nozaka, A.; Nishiwaki, A.; Nagashima, Y.; Endo, S.; Kuroki, M.; Nakajima, M.; Narukawa, M.; Kamisuki, S.; Arazoe, T.; Taguchi, H.; Sugawara, F.; Kamakura, T. Chloramphenicol inhibits eukaryotic Ser/Thr phosphatase and infection-specific cell differentiation in the rice blast fungus. Scientific Reports 2019, 9 , 9283, doi: https://doi.org/10.1038/s41598-019-41039-x 